\title{
Antioxidant and Antimicrobial Activity of Cleome droserifolia (Forssk.) Del. and Its Biological Effects on Redox Status, Immunity, and Gut Microflora
}

\author{
Nesrein M. Hashem ${ }^{1, *(D)}$ and Mohamed G. Shehata ${ }^{2}$ (D) \\ 1 Department of Animal and Fish Production, Faculty of Agriculture, Alexandria University, \\ Alexandria 21545, Egypt \\ 2 Department of Food Technology, Arid Lands Cultivation Research Institute, City of Scientific Research and \\ Technological Applications (SRTACITY), New Borg El Arab, Alexandria 21545, Egypt; gamalsng@gmail.com \\ * Correspondence: nesreen.hashem@alexu.edu.eg
}

check for updates

Citation: Hashem, N.M.; Shehata, M.G. Antioxidant and Antimicrobial Activity of Cleome droserifolia (Forssk.) Del. and Its Biological Effects on Redox Status, Immunity, and Gut Microflora. Animals 2021, 11, 1929. https://doi.org/10.3390/ ani11071929

Academic Editors: Cesare Castellini and Ilias Giannenas

Received: 17 May 2021

Accepted: 25 June 2021

Published: 28 June 2021

Publisher's Note: MDPI stays neutral with regard to jurisdictional claims in published maps and institutional affiliations.

Copyright: (c) 2021 by the authors. Licensee MDPI, Basel, Switzerland. This article is an open access article distributed under the terms and conditions of the Creative Commons Attribution (CC BY) license (https:/ / creativecommons.org/licenses/by/ $4.0 /)$.
Simple Summary: The antioxidant, antimicrobial, and immunomodulatory activities of the Cleome droserifolia (Forssk.) Del. (Cd) shrub were investigated considering the biological activity of its phytogenic compounds. Cd shrub encompasses several phenolic compounds, mainly phenolic acids, such as benzoic acid. The methanolic extract of $\mathrm{Cd}$ exhibited strong in vitro antioxidant and antimicrobial activities. Anin vivo study using rabbits as an animal model confirmed the ability of a powder of $\mathrm{Cd}$ aerial parts to improve humoral and innate immunity, as well as gastrointestinal microbiota homeostasis. In conclusion, $\mathrm{Cd}$ shrub represents a novel source of secondary active metabolites that can be employed as antibiotic alternative in the livestock production field and/or in human pharmaceutical applications.

Abstract: This study aimed to investigate the antioxidant, antimicrobial, and immunomodulatory activities of a Cleome droserifolia (Forssk.) Del. (Cd) shoot methanolic extracts considering the biological activity of its phytogenic compounds. For this purpose, the $\mathrm{Cd}$ phenolic compounds were detected, and an in vitro evaluation of the antioxidant and antimicrobial activities of the Cd extract was performed. For a biological evaluation, $30 \mathrm{v}$-line rabbits were randomly distributed into three groups with treatments including: a basal diet without $\mathrm{Cd}$ shoots powder supplement (C group) or supplemented with 1.25- (Cdl group) or 2.5 (Cdh group)-mg Cd/kg dry matter (DM). The Cd extract showed a linear scavenging activity for 2,2-diphenyl-1-picrylhydrazyl and 2,2'-azino-bis (3-ethylbenzothiazoline-6-sulfonic acid), with the maximal activity observed at a concentration of $1 \mathrm{mg} / \mathrm{mL}$. A total of 16 phenolic compounds were identified by reverse-phase high-performance liquid chromatography (RP-HPLC) in the Cd methanolic extract, among which benzoic acid, rutin, ellagic acid, naringenin, and o-coumaric acid were the major compounds. The methanolic extract of Cd showed inhibitory actions against microbial pathogen species. The in vivo study showed that the two concentrations of Cd significantly improved the redox status of the blood plasma and lysozyme activity. Treatment with Cdh significantly decreased the levels of interleukin- $\beta 1$ in the blood plasma compared with the control. Moreover, the two concentrations of $\mathrm{Cd}$ significantly increased the counts of intestinal and cecal yeast and Lactobacillus species and decreased the Salmonella and Coliform species compared with the control. The aerial parts of the Cd shrub had strong antioxidant, antimicrobial, and immunomodulatory activities, which can improve the overall health status and seem to be related to its impressive range of biologically active phenolic compounds.

Keywords: phytogenic; phenols; antioxidant; antimicrobial activity; immunity

\section{Introduction}

Medicinal plants can serve as a natural source of therapeutic drugs, nutraceuticals/food supplements, and feed additives that can be safely used to improve human 
and animal health. The interest in exploring plants as a new source of different drugs, specifically antimicrobials, has increased in recent decades as an attempt to fight multidrugresistant bacteria [1,2]. Among the medicinal plants, the Cleome genus is one of the largest genera belonging to the family Cleomaceae. This genus encompasses about 180-200 species that are geographically distributed in Egypt, Libya, Palestine, Syria, and other arid and semi-arid regions [3]. Moreover, they are perennial, low, and aromatic cushion-like shrubs with a length of $25-60 \mathrm{~cm}$ that exhibit intricately branched stems and broad oval-shaped, three-nerved leaves with swollen glandular hairs [3,4]. The shrubs that belong to this genus have medicinal and ecological importance. Cleome genus shrubs are well-known in folk medicine for treating stomachache, skin allergies, and open wounds, as well as for exhibiting anticancer and hepatoprotective properties [5-7]. In addition, Cleome genus shrubs have shown strong antidiabetic properties; the aqueous extract of Cleome has been found to contain a very high percentage of flavonols that showed $63.3 \%$ activity, similar to that of the metformin synthetic drug [8]. Cleome genus shrubs have antioxidant, antiparasitic, and antimicrobial activities [6]. These biological effects are related to the vast array of secondary metabolites that occur naturally in Cleome genus shrubs. Several terpenes, flavonoids, glucosinolates, anthocyanin alkaloids, and polyphenols have been isolated from Cleome genus shrubs [3]. Given these biological activities of Cleome genus shrubs, additional studies are required to explore the active secondary metabolites of these shrubs and their eligibility to innovate natural feed and food supplements that could be applied for improving animal and human health. Therefore, this study was devoted to the evaluation of the antioxidant, antimicrobial, and immunomodulatory properties of Cleome droserifolia (Forssk.) Del., the most famous species among the Cleome genus in Egypt, considering phenolic compounds as active secondary metabolites.

\section{Materials and Methods}

2.1. In Vitro Evaluation of Cleome droserifolia (Forssk.) Del.

\subsubsection{Plant Source and Extraction}

Shoots of Cleome droserifolia (Forssk.) Del. (Cd) were collected at "Megerah" Valley, Dahab, the Eastern Desert, South Sina, Egypt during the month of November 2018. The plant was authenticated by the Plant Protection and Biomolecular Diagnosis Department, STR-City, New Borg El-Arab, Egypt. The collected shoots were pooled, dried at $40{ }^{\circ} \mathrm{C}$ for $72 \mathrm{~h}$, and milled through a $0.25-\mathrm{mm}$ screen to obtain a fine powder. Representative samples of dried $\mathrm{Cd}$ powder were extracted and pooled for evaluating the phenolic content, antioxidant activity, and antimicrobial activity of the plant. Briefly, each $100 \mathrm{~g}$ of dried $\mathrm{Cd}$ powder was extracted in $1000 \mathrm{~mL}$ of hydro-methanolic solution $(700-\mathrm{mL}$ methanol and $300-\mathrm{mL}$ water; $70 \%$ ) at $40{ }^{\circ} \mathrm{C}$ for $72 \mathrm{~h}$. The extract was filtered through Whatman No. 1 filter paper (Whatman No. 1, Camlab, Cambridge, UK). The collected filtrate was evaporated at $45^{\circ} \mathrm{C}$ to complete dryness, and the residues were then stored at $-20{ }^{\circ} \mathrm{C}$ for further analyses.

\subsubsection{Determination of Total Phenolic and Total Flavonoid Content}

The concentrations of total phenols (TPC) and total flavonoids (TFC) of the Cd methanolic extract were colorimetrically (T80 UV/Vis spectrometer PG Instruments LDT, Leicestershire, UK) determined using the Folin-Ciocalteu and aluminum trichloride $\left(\mathrm{AlCl}_{3}\right)$ methods, respectively. Gallic acid (GA) and catechol (CAT) were used as a standard for TPC and TFC measurements, respectively. Results were expressed as mg of GA equivalent/g of the DM extract (mg GA/g DM) and mg of CAT equivalent/g of the DM extract (mg CAT/g DM), as in reference [9].

\subsubsection{Determination of Polyphenol Content}

All analytical chemicals were gradient grade for the HPLC analysis. All chemicals and standards were purchased from Sigma-Aldrich ${ }^{\circledR}$ (Merck KGaA, Darmstadt, Germany). The polyphenol profile of the $\mathrm{Cd}$ extract was assessed using reverse-phase high-performance 
liquid chromatography (RP-HPLC) in an apparatus coupled with a variable wavelength detector (VWD; Agilent1260 infinity HPLC Series, Agilent, Santa Clara, CA, USA) at a wavelength of $284 \mathrm{~nm}$ and fitted with a C18 column (a Kinete ${ }^{\circledR} 51 \mathrm{Jm}$ EVO C18, $106 \times 4.6 \mathrm{~mm}$, Phenomenex, Torrance, CA, USA) that was maintained at $35{ }^{\circ} \mathrm{C}[10,11]$. The flow rate of the binary elution phase (A: $0.1 \%$ trifluoroacetic acid in water and B: $50 \%$ acetonitrile, $49.8 \%$ water, and $0.2 \%$ trifluoroacetic acid) was kept at $1.0 \mathrm{~mL} / \mathrm{min}$ using a ternary linear elution gradient (A: $0.2 \%$ phosphoric acid, B: 100\% methanol, and C: $100 \%$ acetonitrile). The measured values were expressed as $\mu \mathrm{g} / \mathrm{g}$ of dry weight ( $\mu \mathrm{g} / \mathrm{g} \mathrm{DM})$ of $\mathrm{Cd}$.

\subsubsection{Determination of Antioxidant Activity}

The antioxidant activity of the $\mathrm{Cd}$ methanolic extract was assessed via a radical scavenging assay using 2,2-diphenyl-1-picrylhydrazyl (DPPH) and 2,2'-azino-bis (3-ethylbenzo thiazoline-6-sulfonic acid) (ABTS)-based methods [12]. The antiradical activity of the Cd methanolic extract was determined based on its ability to scavenge the DPPH free radical. In brief, a mixture of $500 \mu \mathrm{L}$ of the extract at various concentrations with $375 \mu \mathrm{L}$ of ethanol and $125 \mu \mathrm{L}$ of DPPH solution ( $0.02 \%$ in ethanol) was prepared. A control containing $875 \mu \mathrm{L}$ of ethanol and $125 \mu \mathrm{L}$ of DPPH solution was also prepared. After incubation for $60 \mathrm{~min}$ in the dark, the absorbance at $517 \mathrm{~nm}$ was measured. The antiradical activity was determined using the following formula: inhibition activity $(\%)$ of the DPPH radical $=$ (absorbance (Abs) of the control - Abs of the sample/Abs of the sample) $\times 100$. To determine the scavenging activity of the ABTS radical, two stock solutions were prepared as follows: 7-mM ABTS and 2.4-mM potassium persulfate. The working solution was then prepared by mixing the two stock solutions in equal quantities and allowing them to react for $12 \mathrm{~h}$ at room temperature in the dark. The solution was then diluted by mixing $1 \mathrm{~mL}$ of the ABTS solution with $60 \mathrm{~mL}$ of methanol to obtain an absorbance of $0.802 \pm 0.005$ units at $734 \mathrm{~nm}$, as assessed using a spectrophotometer (T80 UV/Vis spectrometer PG Instruments $\mathrm{LDT}$, Leicestershire, UK). One milliliter of the $\mathrm{Cd}$ methanolic extract was allowed to react with $1 \mathrm{~mL}$ of the ABTS solution, and the absorbance was set at $734 \mathrm{~nm}$ after $7 \mathrm{~min}$ using a spectrophotometer. The antiradical activity was determined using the following formula: inhibition activity of ABTS $(\%)=$ (absorbance (Abs) of the control-Abs of the sample/Abs of the control) $\times 100$. The DPPH and ABTS scavenging activities of the Cd extract were compared with the scavenging activity of ascorbic acid.

\subsubsection{In Vitro Antimicrobial Activity of Cleome droserifolia (Forssk.) Del.}

The agar well diffusion method was used to determine the diameters of the inhibition zones of the $\mathrm{Cd}$ methanolic extract against five pathogenic strains, including Staphylococcus aureus NCTC 10788, Salmonella senftenberg ATCC 8400, Escherichia coli BA 12296B, Candida albicans ATCC MYA-2876, and Listeria monocytogenes ATCC 19116. Tests were performed in triplicate, and the results are presented as the mean \pm standard error of the mean (SE) [13].

\subsection{In Vivo Evaluation of Cleome droserifolia (Forssk.) Del.}

\subsubsection{Experimental Design}

Thirty v-line (a maternal line selected for high litter size at weaning) male rabbits (70 days of age) weighing $1224.0 \pm 19.91 \mathrm{~g}$ at allocation were individually placed in galvanized wire cages $\left(40 \times 50 \times 35 \mathrm{~cm}^{3}\right)$ and housed at the rabbitry of the Laboratory of Rabbit Physiology Research, Agricultural Experimental Station, Faculty of Agriculture, Alexandria University, Alexandria, Egypt. Rabbits were kept under similar management and hygiene conditions. Rabbits were equally allocated into three groups and received the same standard diet supplemented with 0 (C group), 1.25 (Cdl group), or 2.5 (Cdh group) $\mathrm{g}$ of $\mathrm{Cd}$ shoots powder $/ \mathrm{kg}$ of DM diet for 4 consecutive weeks (day 0: first day of the treatment and day 30: last day of the treatment). Rabbits were fed on a pellet diet containing (g/ kg): 300 alfalfa hay, 230 wheat bran, 180 soybean, 180 barley, 60 yellow maize, 30 molasses, $10 \mathrm{NaCl} 10$, and $\mathrm{CaCo}_{3}(18.90 \% \mathrm{CP}$ and $10.25-\mathrm{MJ} / \mathrm{kg}$ digestible energy), covering their daily nutritional requirements according to NRC (1977) [14]. The values of 
TPC and TFC of the standard diet were $12.81 \pm 0.83-\mathrm{mg} \mathrm{GA} / \mathrm{g}$ DM and $4.16 \pm 0.22-\mathrm{mg}$ $\mathrm{CAT} / \mathrm{g} \mathrm{DM}$, respectively. The half-maximal inhibitory concentration $\left(\mathrm{IC}_{50}\right)$ of the standard diet was $1730 \pm 3.12 \mu \mathrm{g} / \mathrm{mL}$ for DPPH and $1492 \pm 4.21 \mu \mathrm{g} / \mathrm{mL}$ for ABTS.

Weight, feed consumption, and rectal temperature were recorded weekly for each rabbit. Fecal score was also recorded twice a week for each rabbit and assigned one of the following scores: 1 , normal; 2 , soft; 3 , mixed soft and liquid; and 4, completely liquid [15].

2.2.2. Blood Plasma Hemato-Biochemical Attributes, Redox Status Indicator, and Immunological Variables

Blood samples were collected from the marginal ear vein of rabbit ( $n=6$ /group) on experimental days 0 and 30 . Each blood sample was divided into two subplots: the first subplot (whole blood) was used to assess the hematological and innate immune variables, and the second subplot was centrifuged at $2000 \times g$ for $20 \mathrm{~min}$ at $4{ }^{\circ} \mathrm{C}$ to obtain plasma samples. The plasma samples were stored at $-20^{\circ} \mathrm{C}$ pending analyses. The counts of red and white blood cells and the packed corpuscular volume were determined. A differential white blood cell count test was also performed to identify the percentage of specific white blood cells [1]. The concentrations of hemoglobin were assessed colorimetrically using commercial kits (Biosystems S.A., Costa Brava, Barcelona, Spain). Phagocytic activity (PA) and the phagocytic index (PI) were determined. A sample of whole blood was mixed (1:1) with Staphylococcus albus $\left(1.0 \times 10^{5}\right.$ cells $\left./ \mathrm{mL}\right)$ in phosphate-buffered solution (PBS; $\mathrm{pH}=7.2$ ) and incubated for $30 \mathrm{~min}$ at $37^{\circ} \mathrm{C}$. A drop of the mixture was transferred to a slide, and a smear was prepared. After drying, the smear was fixed with methanol for $30 \mathrm{~min}$, then processed using Levowitz-Weber staining for $2 \mathrm{~min}$ and washed three times with distilled water [16]. Phagocytic cells and engulfed bacteria were counted on a light microscope at a magnification of $100 \times$, and the PA and PI were calculated as follows: PA $=$ percentage of phagocytic cells containing bacterial cells and PI = number of bacterial phagocytosed cells/number of phagocytic cells [16].

The plasma lysozyme activity (LA) was determined using lyophilized Micrococcus lysodekticus as the substrate in PBS $(\mathrm{pH}=6.4)$. A plasma sample of $50 \mu \mathrm{L}$ was mixed with $3 \mathrm{~mL}$ of bacterial suspension. The absorbance of the mixture was measured at $570 \mathrm{~nm}$ twice at time 0 (directly after plasma addition; A0) and again after incubation of the mixture for $30 \mathrm{~min}(\mathrm{~A} 30)$ at $37^{\circ} \mathrm{C}$. The LA was calculated using the following formula: $\mathrm{LA}=(\mathrm{A} 0-\mathrm{A} 30) / \mathrm{A} 30$ [17]

Blood plasma metabolites, including total protein, albumin, and glucose, were determined using commercial kits obtained from Biodiagnostics (Giza, Egypt). The linearity of the methods was up to $10.0 \mathrm{~g} / \mathrm{dL}, 7.0 \mathrm{~g} / \mathrm{dL}$, and $500 \mathrm{mg} / \mathrm{dL}$ for the total protein content, albumin content, and glucose, respectively. The total antioxidant capacity and malondialdehyde concentration in the plasma were also determined as indicators of the antioxidant and redox status of plasma using commercial kits (Biodiagnostics, Giza, Egypt), according to the instructions of the manufacturer. The linearities of the methods were up to $120 \mathrm{U} / \mathrm{mL}, 1000 \mathrm{mg} / \mathrm{dL}$, and $2 \mathrm{mM}$, respectively. The enzyme-linked immunosorbent assay (ELISA) technique was applied to assess the concentrations of immunoglobulin $\mathrm{G}$ ( $\mathrm{IgG}$ ), immunoglobulin E (IgE), and immunoglobulin A (IgA) (IBL America Immuno-Biological Laboratories, Inc., Spring Lake Park, MN, USA). According to the manufacturer's instructions, the sensitivity and specificity of the assays exceeded $96 \%$. Interleukin- $1 \beta$ (IL-1 $\beta$ ) was determined in the blood plasma samples (Cat. No. MBS262525, MyBioSource, Inc., San Diego, CA, USA). The lower limit of detection was $5 \mathrm{pg} / \mathrm{mL}$, and the intra- and inter-assay precisions were $\geq 8 \%$ and $\geq 12 \%$, respectively.

\subsubsection{Intestinal and Cecal Microflora Composition}

At the end of the experiment (day 30), six rabbits were randomly chosen from each group and were slaughtered [1]. The intestine and cecum were ligated with light twine before separating the cecum from the small intestine. The first part of small intestinal tract and the last part of the cecum were removed and stored in sterile bags at $-4{ }^{\circ} \mathrm{C}$. For bacterial enumeration, the intestinal and cecal contents were separately diluted 10 -fold (i.e., 
$10 \% w / v)$ with sterile ice-cold anoxic PBS (0.1 M; pH 7.0) and subsequently homogenized for $3 \mathrm{~min}$ in a stomacher. Each homogenate was serially diluted from 10-1 to 10-7. Dilutions were subsequently plated in duplicate on selective agar media for target bacterial groups, and the enumeration results were expressed as colony-forming units (cfu) $\log 10 / \mathrm{g}$. In particular, Sabouraud Dextrose Agar for yeast counts; de Man, Rogosa and Sharpe (MRS) agar for LAB counts; MacConkey agar media for coliform counts; and Salmonella and Shigella agar plates for Salmonella counts were used. Plates were then incubated at $37^{\circ} \mathrm{C}$ for 24 to $72 \mathrm{~h}[18]$.

The procedures and methods performed to evaluate Cd's in vitro and in vivo biological activities are shown in Figure 1.

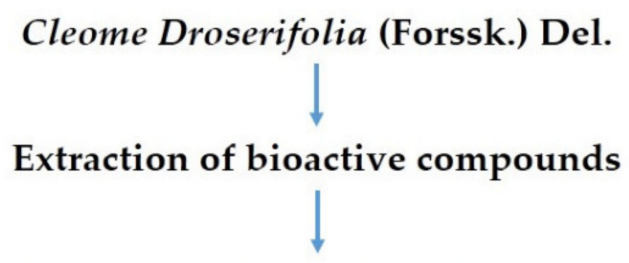

Determination of Total Phenolic and flavonoid Content, Antioxidant, Antimicrobial activity

Determination of Polyphenols by HPLC

In vivo Evaluation of Cleome droserifolia (Forssk.) Del Thirty male rabbits (70 days old) weighting $1224.0 \pm 19.91 \mathrm{~g}$

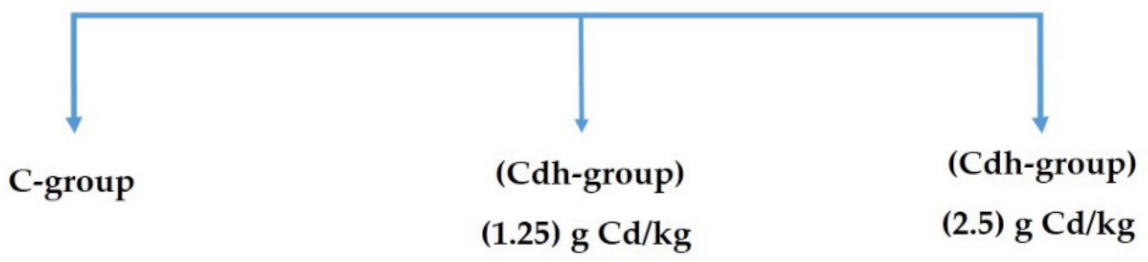

Blood plasma Haemato-biochemical Attributes

$>$ Redox Status Indicator

$>$ Immunological Variables

$>$ Intestinal and Cecal Microflora Composition

Figure 1. Flow chart of in vitro and in vivo evaluations of Cleome droserifolia (Forssk.) Del.

\subsection{Statistical Analysis}

Statistical Analysis System [19] software was used for analyzing all results. Body weight; feed intake; fecal score; rectal temperature; and hematological, biochemical, and immunological variables were analyzed by the Generalized Linear Model (GLM) method using the following model: $y \mathrm{ij}=\mu+\mathrm{Ti}+$ eij, in which yij is the observed value of the dependent variable, $\mu$ is the overall mean, $T i$ is the fixed effect of the $i$ th treatment, and eij is the residual error. Comparisons between treatment means were performed using Duncan's multiple range test. All results were expressed as the mean $\pm \mathrm{SE}$. Significance was set at $p \leq 0.05$. 


\section{Results}

3.1. RP-HPLC Assessment of Total Phenol and Flavonoid Contents and Phenolic Compound Profile

The values of TPC and TFC of the Cd methanolic extract were 32.55- $\pm 2.26-\mathrm{mg}$ GA/g $\mathrm{DM}$ and 12.78- \pm 1.86 -mg CAT/g DM, respectively (Table 1 ). The phenolic profile of the $\mathrm{Cd}$ methanolic extract detected by RP-HPLC is shown in Table 1 . These results revealed that, among the 16 phenolic compounds identified here, the most abundant phenolic compounds, ranging between 1460.62 and $7657.15 \mu \mathrm{g} / \mathrm{g} \mathrm{DM}$, were benzoic acid, rutin, ellagic acid, naringenin, and o-coumaric acid. The second-most abundant phenolic compounds, ranging between 432.14 and $264.06 \mu \mathrm{g} / \mathrm{g} \mathrm{DM}$, were rosmarinic acid, p-hydroxybenzoic acid, resveratrol, kaempferol, quercetin, and ferulic acid. The third-most abundant phenolic compounds were caffeic acid, p-coumaric acid, chlorogenic acid, catechin, syringic acid, and catechin, which were detected in low quantities, ranging between 10.43 and $59.59 \mu \mathrm{g} / \mathrm{g}$ DM.

Table 1. Contents of the total phenolic, total flavonoid, and individual phenolic compounds (as detected by reverse-phase high-performance liquid chromatography; RP-HPLC) in the Cleome droserifolia (Forssk.) Del. methanolic extract (Cd extract).

\begin{tabular}{cc}
\hline Analysis & Content \\
\hline Total phenols (mean \pm SE, mg GA equivalent/g DM) & $32.55 \pm 0.23$ \\
Total flavonoids (mean \pm SE, mg CAT equivalent/g DM) & $12.78 \pm 0.19$ \\
Individual detected phenolic compounds $(\mu \mathrm{g} / \mathrm{g}$ DM) & \\
Benzoic acid & 7657.15 \\
Rutin & 2987.63 \\
Ellagic acid & 1641.98 \\
Naringenin & 1516.25 \\
o-Coumaric acid & 1460.62 \\
Rosmarinicacid & 955.27 \\
p-Hydroxybenzoic acid & 924.57 \\
Resveratrol & 895.77 \\
Kaempferol & 778.80 \\
Quercetin & 432.14 \\
Ferulic acid & 264.06 \\
Caffeic acid & 59.59 \\
p-Coumaric acid & 39.55 \\
Chlorogenic acid & 29.33 \\
Syringic acid & 19.29 \\
Catechin & 10.43 \\
\hline
\end{tabular}

$\mathrm{GA}=$ gallic acid, $\mathrm{CAT}=$ catechol, and $\mathrm{DM}=$ dry matter.

\subsection{Antioxidant Activity of the Cd Extract}

The antiradical capacity (scavenging activity) of the $\mathrm{Cd}$ methanolic extract, as determined by the DPPH and ABTS colorimetric tests, is shown in Table 2. The percent inhibition values of the $\mathrm{Cd}$ extract were not much greater than those of the standard antioxidant (ascorbic acid). The Cd extract showed a linear increase in the DPPH and ABTS radical scavenging activities with increasing concentrations, reaching $66.09 \% \pm 1.92 \%$ and $81.14 \% \pm 1.26 \%$ scavenging activity for DPPH and ABTS, respectively, at concentrations of $1000 \mu \mathrm{g} / \mathrm{mL}$ vs. $87.52 \% \pm 0.62 \%$ and $92.44 \% \pm 0.14 \%$ for ascorbic acid. The half-maximal inhibitory concentration $\left(\mathrm{IC}_{50}\right)$ of the Cd extract was $470.27 \pm 2.24 \mu \mathrm{g} / \mathrm{mL}$ for $\mathrm{DPPH}$ and $387.53 \pm 3.11 \mu \mathrm{g} / \mathrm{mL}$ for ABTS vs. $16.62 \pm 0.91 \mu \mathrm{g} / \mathrm{mL}$ and $14.03 \pm 0.67 \mu \mathrm{g} / \mathrm{mL}$ for ascorbic acid, respectively. 
Table 2. Antioxidant activity of the Cleome droserifolia (Forssk.) Del. methanolic extract (Cd extract), as assessed by the 2,2-diphenyl-1-picrylhydrazyl (DPPH) and 2,2'-azino-bis (3-ethylbenzothiazoline6-sulfonic acid (ABTS) tests.

\begin{tabular}{ccccc}
\hline \multirow{2}{*}{$\begin{array}{c}\text { Antioxidant } \\
\text { Concentration }(\mu \mathrm{g} / \mathrm{mL})\end{array}$} & \multicolumn{2}{c}{ DPPH Scavenging Activity, \% } & \multicolumn{2}{c}{ ABTS Scavenging Activity, \% } \\
\cline { 2 - 5 } & Cd Extract & Ascorbic Acid & Cd Extract $^{\text {Ascorbic Acid }}$ \\
\hline 7.81 & $12.87 \pm 0.91^{\mathrm{b}}$ & $62.66 \pm 0.12^{\mathrm{a}}$ & $23.16 \pm 0.76^{\mathrm{b}}$ & $64.58 \pm 0.24^{\mathrm{a}}$ \\
15.6 & $16.03 \pm 0.84^{\mathrm{b}}$ & $75.68 \pm 0.45^{\mathrm{a}}$ & $25.09 \pm 0.84^{\mathrm{b}}$ & $76.10^{\mathrm{a}} \pm 0.92^{\mathrm{a}}$ \\
31.25 & $26.88 \pm 0.86^{\mathrm{b}}$ & $77.6 \pm 0.86^{\mathrm{a}}$ & $34.16 \pm 0.92^{\mathrm{b}}$ & $80.21^{\mathrm{a}} \pm 1.04^{\mathrm{a}}$ \\
62.5 & $31.45 \pm 1.12^{\mathrm{b}}$ & $79.11 \pm 1.14^{\mathrm{a}}$ & $43.79 \pm 1.16^{\mathrm{b}}$ & $82.30 \pm 0.86^{\mathrm{a}}$ \\
125 & $34.56 \pm 1.24^{\mathrm{b}}$ & $80.20 \pm 0.88^{\mathrm{a}}$ & $49.28 \pm 1.13^{\mathrm{b}}$ & $85.12^{\mathrm{b}} \pm 0.45^{\mathrm{a}}$ \\
250 & $46.87 \pm 1.16^{\mathrm{b}}$ & $83.2 \pm 0.62^{\mathrm{a}}$ & $54.03 \pm 0.76^{\mathrm{b}}$ & $88.07 \pm 0.93^{\mathrm{a}}$ \\
500 & $53.16 \pm 0.85^{\mathrm{b}}$ & $85.4 \pm 0.56^{\mathrm{a}}$ & $64.51 \pm 0.85^{\mathrm{b}}$ & $89.02 \pm 0.88^{\mathrm{a}}$ \\
1000 & $66.09 \pm 1.92^{\mathrm{b}}$ & $87.52 \pm 0.62^{\mathrm{a}}$ & $81.14 \pm 1.26^{\mathrm{b}}$ & $92.44 \pm 0.14^{\mathrm{a}}$ \\
& Half-maximal inhibitory concentration & & \\
$\left(\mathrm{IC} C_{50}\right)(\mu \mathrm{g} / \mathrm{mL})$ & $470.27 \pm 2.24^{\mathrm{a}}$ & $16.62 \pm 0.91^{\mathrm{b}}$ & $387.53 \pm 3.11^{\mathrm{a}}$ & $14.03 \pm 0.67^{\mathrm{b}}$
\end{tabular}

The mean values indicated in the same rows within variable with different superscripts (a and b) were significantly different $(p<0.05)$.

\subsection{In Vitro Antimicrobial Activity}

The methanolic extract of $\mathrm{Cd}$ exhibited striking inhibitory actions against Staphylococcus aureus NCTC 10788, Salmonella senftenberg ATCC 8400, Escherichia coli BA 12296, and Candida albicans ATCC MAY-2876 (Table 3 and Figure 2). Conversely, the Cd extract was inactive against Lissteria monocytogenes ATCC 19116 (Table 3 and Figure 2).

Table 3. In vitro antimicrobial activity of Cleome droserifolia (Forssk.) Del. against pathogenic microorganisms.

\begin{tabular}{cc}
\hline Pathogens Microorganisms & Inhibition Zone (mm) \\
\hline Staphylococcus aureus NCTC 10788 & $15.63 \pm 1.30^{\mathrm{a}}$ \\
Salmonella senftenberg ATCC 8400 & $12.70 \pm 0.81^{\mathrm{a}}$ \\
Escherichia coli BA 12296 & $8.06 \pm 1.72^{\mathrm{b}}$ \\
Candida albicans ATCC MYA-2876 & $7.16 \pm 2.92^{\mathrm{b}}$ \\
Listeria monocytogenes ATCC 19116 & $\mathrm{NI}$ \\
\hline
\end{tabular}

NI, no inhibitory action.

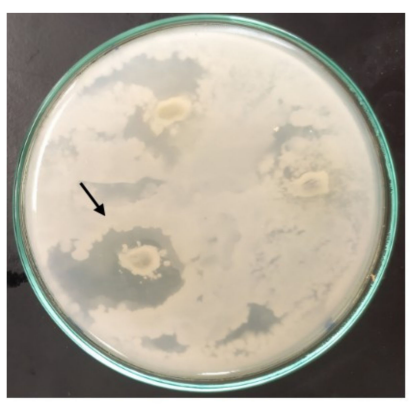

Listeria monocytogenes ATCC 19116

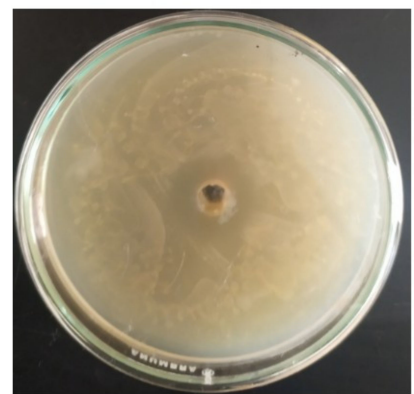

Salmonella senftenberg ATCC 8400

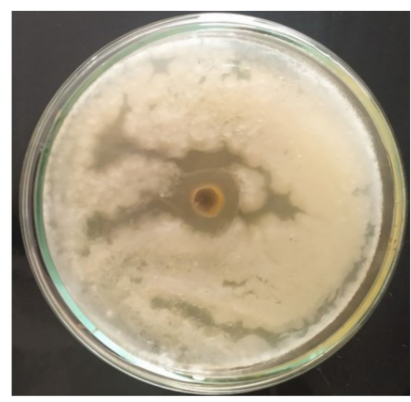

Staphylococcus aureus NCTC 10788

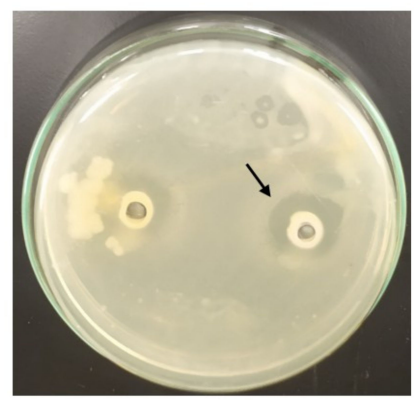

Escherichia coli BA 12296

Figure 2. Antimicrobial activity of Cleome droserifolia (Forssk.) Del. extract against pathogenic microorganisms. 


\subsection{Effect of Treatment on Weight, Feed Intake, and Health Indicators in Rabbits}

The treatments with different concentrations of $\mathrm{Cd}(0,1.25$, or $2.5 \mathrm{~g} / \mathrm{kg}$ of DM diet) did not affect the overall mean body weight and feed intake of rabbits during the 30-day experimental period (Table 4). The treatment with Cdh tended $(p<0.085)$ to decrease the fecal score compared with the other treatments (Table 4). Compared with the control, the two concentrations of $\mathrm{Cd}$ decreased significantly the overall mean rectal temperature (Table 4).

Table 4. Body weight, feed intake, fecal score, and rectal temperature of rabbits treated with different concentrations of Cleome droserifolia (Forssk.) Del. (Cd) (0: C, Cdl: $1.25 \mathrm{~g} / \mathrm{kg}$ of DM diet, or Cdh: $2.5 \mathrm{~g} / \mathrm{kg}$ of DM diet).

\begin{tabular}{ccccc}
\hline \multirow{2}{*}{ Treatment } & \multicolumn{3}{c}{ Variable (Mean \pm Standard Error of the Mean, $\boldsymbol{n}=\mathbf{1 0}$ /Treatment) } \\
\cline { 2 - 5 } & Body Weight, $\mathbf{g}$ & Feed Intake, g/day & Fecal Score & Rectal Temperature, ${ }^{\circ} \mathbf{C}$ \\
\hline C & $1454 \pm 37.01$ & $99.47 \pm 17.36$ & $1.19 \pm 0.083$ & $39.07 \pm 0.112^{\mathrm{a}}$ \\
Cdl & $1413 \pm 33.75$ & $100.06 \pm 15.88$ & $1.21 \pm 0.073$ & $38.80 \pm 0.091^{\mathrm{b}}$ \\
Cdh & $1393 \pm 37.82$ & $99.14 \pm 17.31$ & $1.13 \pm 0.063$ & $38.74 \pm 0.123^{\mathrm{b}}$ \\
$p$-Value & 0.478 & 0.968 & 0.085 & 0.007 \\
\hline
\end{tabular}

The mean values indicated in the same columns with different superscripts ( $a$ and $b$ ) were significantly different $(p<0.05)$.

\subsection{Effect of Treatment on Hemato-Chemistry and Redox Status}

The hematological attributes, blood plasma metabolites, and antioxidant activity of rabbits treated with different concentrations of $\mathrm{Cd}(0,1.25$, or $2.5 \mathrm{~g} / \mathrm{kg}$ of DM diet) are shown in Table 5. No differences were observed for any of the variables at day 0 , confirming the homogeneity of the experimental groups before the beginning of the treatment. At day 30 (the end of the experimental period), the treatment had not affected the hematological attributes or blood plasma metabolites. However, both concentrations of Cd significantly increased the levels of the total antioxidant activity and significantly decreased the levels of malondialdehyde in the blood plasma.

Table 5. Hematological attributes, blood plasma metabolites, and antioxidant activity of rabbits treated with different concentrations of Cleome droserifolia (Forssk.) Del. (Cd) (0: C, Cdl: $1.25 \mathrm{~g} / \mathrm{kg}$ of DM diet, or Cdh: $2.5 \mathrm{~g} / \mathrm{kg}$ of DM diet).

\begin{tabular}{|c|c|c|c|c|c|c|c|c|}
\hline \multirow[b]{2}{*}{ Treatment } & \multicolumn{8}{|c|}{ Variable (Mean \pm Standard Error of the Mean, $n=6$ ) } \\
\hline & $\begin{array}{c}\text { Red Blood } \\
\text { Cell Count } \\
\left(10^{6} / \mathrm{mL}\right)\end{array}$ & $\begin{array}{c}\text { Packed } \\
\text { Cell } \\
\text { Volume(\%) }\end{array}$ & $\begin{array}{l}\text { Hemoglobin, } \\
\text { g/dL }\end{array}$ & $\begin{array}{l}\text { Total } \\
\text { Protein, } \\
\text { g/dL }\end{array}$ & $\begin{array}{l}\text { Albumin, } \\
\text { g/dL }\end{array}$ & $\begin{array}{l}\text { Glucose, } \\
\text { mg/dL }\end{array}$ & $\begin{array}{c}\text { Total } \\
\text { Antioxidant } \\
\text { Capacity, } \\
\text { Mm/L }\end{array}$ & $\begin{array}{c}\text { Malondialdehyde, } \\
\mathrm{nmol} / \mathrm{mL}\end{array}$ \\
\hline \multicolumn{9}{|l|}{ At day 0} \\
\hline $\mathrm{C}$ & $6.31 \pm 1.01$ & $32.67 \pm 2.45$ & $10.16 \pm 0.32$ & $6.34 \pm 0.15$ & $4.37 \pm 0.11$ & $93.61 \pm 2.27$ & $492.75 \pm 0.53$ & $5.23 \pm 0.43$ \\
\hline Cdl & $5.85 \pm 1.09$ & $33.05 \pm 3.45$ & $10.79 \pm 0.58$ & $6.72 \pm 0.19$ & $4.01 \pm 0.07$ & $91.51 \pm 1.15$ & $425.40 \pm 1.64$ & $4.92 \pm 0.06$ \\
\hline $\mathrm{Cdh}$ & $6.36 \pm 0.97$ & $34.45 \pm 3.47$ & $10.58 \pm 0.79$ & $6.65 \pm 0.27$ & $4.08 \pm 0.12$ & $93.31 \pm 1.24$ & $430.23 \pm 1.59$ & $5.20 \pm 0.13$ \\
\hline$p$-Value & 0.764 & 0.947 & 0.764 & 0.742 & 0.641 & 0.369 & 0.4752 & 0.379 \\
\hline \multicolumn{9}{|l|}{ At day 30} \\
\hline $\mathrm{C}$ & $5.94 \pm 1.21$ & $31.35 \pm 3.72$ & $10.91 \pm 0.67$ & $6.44 \pm 0.23$ & $4.37 \pm 0.24$ & $91.92 \pm 1.01$ & $440.40 \pm 0.30^{\mathrm{b}}$ & $4.19 \pm 0.25^{\mathrm{a}}$ \\
\hline Cdl & $5.85 \pm 0.98$ & $30.37 \pm 1.99$ & $10.91 \pm 0.37$ & $6.28 \pm 0.24$ & $4.59 \pm 0.06$ & $91.56 \pm 1.62$ & $444.09 \pm 0.95^{\mathrm{a}}$ & $3.83 \pm 0.04^{b}$ \\
\hline $\mathrm{Cdh}$ & $5.61 \pm 1.23$ & $30.01 \pm 2.01$ & $9.86 \pm 0.34$ & $6.14 \pm 0.11$ & $4.38 \pm 0.15$ & $92.41 \pm 0.97$ & $443.37 \pm 0.92^{\mathrm{a}}$ & $3.73 \pm 0.04^{b}$ \\
\hline$p$-Value & 0.967 & 0.641 & 0.143 & 0.281 & 0.287 & 0.258 & 0.034 & 0.002 \\
\hline
\end{tabular}

Mean values indicated in the same columns with different superscripts ( $a$ and $b$ ) were significantly different $(p<0.05)$.

\subsection{Effect of Treatment on Immune Indicators}

3.6.1. Innate Immune System

The innate immune indicators of rabbits treated with different concentrations of $\mathrm{Cd}(0$, 1.25 , or $2.5 \mathrm{~g} / \mathrm{kg}$ of DM diet) are shown in Table 6 . No differences were observed for any of the variables at day 0 , confirming the homogeneity of the experimental groups before the beginning of the treatment. At day 30 (the end of the experimental period), the treatment had not affected the white blood cell count/differential count, PI, or PA. The treatment with Cdh significantly increased the blood plasma lysozyme activity compared with the $\mathrm{C}$ 
and Cdl treatments. Moreover, the treatment with Cdh significantly decreased the levels of interleukin- $\beta 1$ in the blood plasma compared with the $C$ treatment, whereas $C d l$ yielded an intermediate value.

Table 6. Innate immune indicators of rabbits treated with different concentrations of Cleome droserifolia (Forssk.) Del. (Cd) (0: C, Cdl: $1.25 \mathrm{~g} / \mathrm{kg}$ of DM diet, or Cdh: $2.5 \mathrm{~g} / \mathrm{kg}$ of DM diet).

\begin{tabular}{|c|c|c|c|c|c|c|c|c|c|}
\hline \multirow[b]{2}{*}{ Treatment } & \multicolumn{9}{|c|}{ Variable (Mean \pm Standard Error of the Mean, $n=6$ ) } \\
\hline & $\begin{array}{c}\text { White Blood } \\
\text { Cells, } \\
10^{3} / \mathrm{mm}^{3}\end{array}$ & $\underset{\%}{\text { Lymphocytes, }}$ & $\begin{array}{c}\text { Neutrocytes, } \\
\%\end{array}$ & $\begin{array}{c}\text { Echinocytes, } \\
\%\end{array}$ & $\begin{array}{c}\text { Monocytes, } \\
\%\end{array}$ & $\begin{array}{c}\text { Phagocytic } \\
\text { Index }\end{array}$ & $\begin{array}{l}\text { Phagocytic } \\
\text { Activity, \% }\end{array}$ & $\begin{array}{l}\text { Lysozyme } \\
\text { Activity, } \\
\text { U/mL }\end{array}$ & $\begin{array}{c}\text { Interleukin- } \\
\beta 1, \\
\mathrm{pg} / \mathrm{mL}\end{array}$ \\
\hline \multicolumn{10}{|l|}{ At day 0} \\
\hline $\mathrm{C}$ & $7.29 \pm 1.26$ & $39.90 \pm 1.28$ & $38.85 \pm 2.33$ & $12.49 \pm 0.78$ & $13.18 \pm 2.00$ & $1.94 \pm 0.27$ & $24.90 \pm 1.24$ & $0.113 \pm 0.37$ & $16.91 \pm 0.34$ \\
\hline Cdl & $6.47 \pm 0.88$ & $38.88 \pm 1.91$ & $33.75 \pm 5.29$ & $10.79 \pm 1.18$ & $11.65 \pm 2.61$ & $2.04 \pm 0.13$ & $19.39 \pm 0.80$ & $0.092 \pm 0.01$ & $15.21 \pm 0.72$ \\
\hline Cdh & $6.33 \pm 1.42$ & $38.71 \pm 1.99$ & $37.59 \pm 3.32$ & $10.12 \pm 1.09$ & $12.91 \pm 0.69$ & $1.96 \pm 0.41$ & $20.95 \pm 0.12$ & $0.101 \pm 0.01$ & $15.74 \pm 0.82$ \\
\hline$p$-Value & 0.560 & 0.240 & 0.338 & 0.327 & 0.679 & 0.804 & 0.258 & & 0.175 \\
\hline \multicolumn{10}{|l|}{ At day 30} \\
\hline C & $6.49 \pm 0.84$ & $39.56 \pm 1.32$ & $32.69 \pm 1.35$ & $11.74 \pm 0.52$ & $13.22 \pm 1.20$ & $2.10 \pm 0.35$ & $20.56 \pm 1.63$ & $0.104 \pm 0.02^{b}$ & $18.66 \pm 0.22^{\mathrm{a}}$ \\
\hline Cdl & $6.33 \pm 0.56$ & $42.01 \pm 1.68$ & $33.65 \pm 3.05$ & $10.22 \pm 0.65$ & $11.28 \pm 1.53$ & $2.19 \pm 0.54$ & $20.63 \pm 1.01$ & $0.106 \pm 0.12^{b}$ & $17.01 \pm 0.81 \mathrm{ab}$ \\
\hline Cdh & $6.02 \pm 1.40$ & $44.52 \pm 1.21$ & $37.63 \pm 1.92$ & $11.51 \pm 0.89$ & $10.97 \pm 1.37$ & $2.49 \pm 0.24$ & $21.2 \pm 2.01$ & $0.142 \pm 0.01^{a}$ & $15.25 \pm 0.92^{b}$ \\
\hline$p$-Value & 0.449 & 0.123 & 0.236 & 0.531 & 0.195 & 0.446 & 0.561 & 0.046 & 0.001 \\
\hline
\end{tabular}

Mean values indicated in the same columns with different superscripts (a and $b$ ) were significantly different $(p<0.05)$.

\subsubsection{Humoral Immune System}

The humoral immune indicators of rabbits treated with different concentrations of $\mathrm{Cd}(0,1.25$, or $2.5 \mathrm{~g} / \mathrm{kg}$ of DM diet) are shown in Table 7 . No differences were observed for any of the variables at day 0 , confirming the homogeneity of the experimental groups before the beginning of the treatment. At day 30 (the end of the experimental period), the two concentrations of Cd had significantly increased the levels of IgG in the blood plasma compared with the control. Conversely, the treatments did not affect the levels of IgA and IgE in the blood plasma.

Table 7. Humoral immune indicators (immunoglobulins (Igs)) of rabbits treated with different concentrations of Cleome droserifolia (Forssk.) Del. (Cd) (0: C, Cdl: $1.25 \mathrm{~g} / \mathrm{kg}$ of DM diet, or Cdh: $2.5 \mathrm{~g} / \mathrm{kg}$ of DM diet).

\begin{tabular}{cccc}
\hline \multirow{2}{*}{ Treatment } & \multicolumn{2}{c}{ Variable (Mean \pm Standard Error of the Mean, $\boldsymbol{n}=\mathbf{6}$ ) } \\
\cline { 2 - 4 } At day $\mathbf{0}$ & IgG, $\mathbf{~ m g / d L}$ & IgA, $\mathbf{~} \mathbf{d} / \mathbf{d L}$ & IgE, $\mathbf{~ m g} / \mathbf{d L}$ \\
C & & - & \\
Cdl & $981.32 \pm 6.65$ & $84.77 \pm 2.68$ & $7.73 \pm 1.35$ \\
Cdh & $989.90 \pm 10.41$ & $85.79 \pm 4.82$ & $6.69 \pm 0.67$ \\
$p$-Value & 0.516 & $88.47 \pm 3.45$ & $7.99 \pm 0.49$ \\
At day 30 & & 0.329 & 0.1602 \\
C & $974.57 \pm 3.84^{\mathrm{b}}$ & $91.78 \pm 2.39$ & $7.99 \pm 0.78$ \\
Cdl & $987.91 \pm 6.01^{\mathrm{a}}$ & $93.86 \pm 2.78$ & $6.88 \pm 0.38$ \\
Cdh & $982.99 \pm 7.48^{\mathrm{a}}$ & $93.06 \pm 4.26$ & $7.73 \pm 0.28$ \\
$p$-Value & 0.016 & 0.647 & 0.359 \\
\hline
\end{tabular}

Mean values indicated in the same columns with different superscripts (a and b) were significantly different $(p<0.05)$. IgG, immunoglobulin G; IgE, immunoglobulin E; and IgA, immunoglobulin A.

\subsection{Intestinal and Cecal Microflora Composition}

The gastrointestinal (small intestine and cecum) microflora composition of rabbits treated with different concentrations of $\mathrm{Cd}(0,1.25$, or $2.5 \mathrm{~g} / \mathrm{kg}$ of the DM diet) is shown in Table 8. At day 30 (the end of the experimental period), the counts of intestine and cecum Salmonella and Coliform species were significantly reduced in the Cd-treated groups compared with the control group. The two concentrations of $\mathrm{Cd}$ significantly increased the counts of intestinal and cecal yeast and Lactobacillus species compared with the control. 
Table 8. Small intestinal and cecal microflora composition of rabbits treated with different concentrations of Cleome droserifolia (Forssk.) Del. (Cd) (0: C, Cdl: $1.25 \mathrm{~g} / \mathrm{kg}$ of DM diet, or Cdh: $2.5 \mathrm{~g} / \mathrm{kg}$ of DM diet).

\begin{tabular}{|c|c|c|c|c|}
\hline \multirow{2}{*}{ Treatment } & \multicolumn{4}{|c|}{ Variable (Mean \pm Standard Error of the Mean, $n=6$ ) } \\
\hline & Yeast & Lactobacillus & Salmonella & Coliform \\
\hline \multicolumn{5}{|c|}{ Intestinal microflora (log cfu/g) } \\
\hline $\mathrm{C}$ & $4.83 \pm 0.65^{b}$ & $6.80 \pm 0.91^{\mathrm{a}}$ & $5.96 \pm 0.55^{\mathrm{a}}$ & $6.30 \pm 0.70^{\mathrm{a}}$ \\
\hline Cdl & $7.60 \pm 0.52^{a}$ & $8.10 \pm 0.94^{\mathrm{a}}$ & $3.10 \pm 0.65^{b}$ & $4.86 \pm 0.77^{\mathrm{a}}$ \\
\hline Cdh & $8.06 \pm 0.66^{\mathrm{a}}$ & $8.06 \pm 0.70^{\mathrm{a}}$ & $3.13 \pm 0.85^{b}$ & $4.83 \pm 0.85^{\mathrm{a}}$ \\
\hline \multicolumn{5}{|c|}{ Cecal microflora (log cfu/g) } \\
\hline $\mathrm{C}$ & $3.56 \pm 0.81^{b}$ & $5.40 \pm 0.55^{\mathrm{a}}$ & $7.63 \pm 0.86^{\mathrm{a}}$ & $8.13 \pm 0.61^{\mathrm{a}}$ \\
\hline Cdl & $5.60 \pm 1.13^{a}$ & $6.57 \pm 1.70^{\mathrm{a}}$ & $5.50 \pm 0.45^{b}$ & $6.06 \pm 1.30^{b}$ \\
\hline Cdh & $5.27 \pm 0.83^{\mathrm{ab}}$ & $6.93 \pm 1.53^{\mathrm{a}}$ & $5.34 \pm 0.67^{b}$ & $6.20 \pm 0.79^{b}$ \\
\hline
\end{tabular}

\section{Discussion}

The literature on natural antioxidant utilization as stabilizing and protecting agents for biological macromolecular components is vast. This covers many aspects of their activity against, mainly, reactive oxygen species (ROS), whereas other aspects are less-known or totally ignored $[1,12,20]$. Despite their remarkable potential for commercial exploitation, species in the Cleome genus have attracted interest, and they are currently used as folk medicine for treating stomachaches, cancer, and liver disorders $[7,21]$. In this study, the values of TPC and TFC obtained for a Cd methanolic extract were close and/or higher than those documented in the literature. For example, the value of TPC obtained in our study was higher than that reported by Aicha et al. [22] in the leaves of Algerian Cleome L. varieties $(\mathrm{TPC}=35.17-\mathrm{mg}$ GA equivalent $/ \mathrm{g}$ extract and $\mathrm{TFC}=11.35-\mathrm{mg}$ rutin equivalent equivalent/g extract). In another study [21], the TPC was $2.38 \mathrm{mg}$ GA equivalent/g of dried plant extract. It is well-known that the Cleome species are an excellent source of phenolic compounds; however, the variations of the TPC and TFC values among the studied samples could be related to many factors, such as the nature of the agro-ecological zones (soil and fertilizers), plant parameters (plant parts and growth phases), extraction method, and assay procedures [23,24].

The antiradical scavenging activity (antioxidant potential) of the $\mathrm{Cd}$ methanolic extract was assessed using two colorimetric tests (DPPH and ABTS). Both tests confirmed the strong antioxidant activity of the $\mathrm{Cd}$ methanolic extract. These findings are consistent with those of previous studies (DPPH method: reference [25] and ABTS method: reference [26]). In our study, the $\mathrm{IC}_{50}$ value of the $\mathrm{Cd}$ methanolic extract was less than that of ascorbic acid by about 29 -fold. In another study, this difference was only two-fold when the $\mathrm{IC}_{50}$ of the extract was compared with that of CAT, which was used as the standard antioxidant $[25,27]$. In general, these differences in $\mathrm{IC}_{50}$ values can be mainly ascribed to variations in the selection of endpoints, the expression of results even within the same method, and the standard antioxidant used. Therefore, comparisons between the values quantified by different laboratories can be quite difficult $[28,29]$.

The strong activity of the $\mathrm{Cd}$ extract observed here may be attributed to the presence of phenolic and flavonoid compounds, which are known for their antioxidant activity. Phenolic compounds - in particular, flavonoids and phenolic acids-are able to directly scavenge ROS, such as superoxide anion radicals $\left(\mathrm{O}_{2-}\right)$ and hydroxyl radicals $(\mathrm{OH}-)$. They are also able to enhance the expression and activity of antioxidant enzymes via different pathways, such as the nuclear factor erythroid 2-related factor 2 signaling pathway $[23,30]$.

The RP-HPLC analysis performed in our study confirmed the presence of an array of phenolic compounds in the $\mathrm{Cd}$ methanolic extract, i.e., phenolic acids, both hydroxybenzoic acid and hydroxycinnamic acid derivatives, and flavonoids. These findings are in line with those obtained by El-Askary et al. (2019) [4], who detected 20 different phenolic compounds in a water extract of $\mathrm{Cd}$, in which phenolic acids (caffeoyl and feruloylquinic acid 
derivatives) were the major components. Previous studies have reported the presence of numerous active secondary metabolites in Cleome species, including phenolic compounds, terpenes, glucosinolates, tannins, and steroids, with different biological activities $[3,8,21]$. The results of the in vitro antimicrobial activity obtained in our study confirmed the remarkable antimicrobial activity of the $\mathrm{Cd}$ methanolic extract against the Staphylococcus aureus NCTC 10788, Salmonella senftenberg ATCC 8400, Escherichia coli BA 12296 B, and Candida albicans ATCC MYA-2876 pathogen species. The antibacterial activity of the secondary metabolites of the Cleome species against both Gram-positive and Gram-negative bacteria has been reported in previous studies [12,31,32].

In this study, the effects of the inclusion of a powder of Cd shoots, to assess its active secondary metabolites, on the health of animals were evaluated using rabbits as a model. Overall, no negative effects of the inclusion of the powder of Cd shoots in the diets of rabbits were observed regarding the hematological parameters, protein and glucose metabolism, and feed intakes. Moreover, all of these variables were in the normal physiological range reported for rabbits. Blood variables can be analyzed to indicate the animal health status and to aid in detecting different nutritional, environmental, or physical stresses [1]. Moreover, linking in vivo results with the antioxidant properties and in vitro antimicrobial activities of the $\mathrm{Cd}$ methanolic extract supports the biological activity of the secondary metabolites detected in the $\mathrm{Cd}$ methanolic extract. Rabbits that were fed Cd-containing diets had a better redox status and intestinal and cecal microbial homeostasis (lower pathogenic microbes and higher beneficial microbes) than those that were fed the control diet. The antimicrobial activity of the $\mathrm{Cd}$ methanolic extract against pathogen species may be related to the presence of many phenolic compounds with antioxidant and antimicrobial activities. Interestingly, the major phenolic compound detected in the $\mathrm{Cd}$ methanolic extract was benzoic acid. This phenolic acid and its derivatives can exert antioxidant effects against various types of ROS by reducing their overproduction [33]. These components also possess antibacterial and antifungal proprieties by inhibiting the microbial active uptake of several essential amino acids [34]. Based on such properties, $\mathrm{Cd}$ supplements could be used as an adjuvant in treating many oxidative stress-induced diseases without any detected harm. Moreover, the naringenin, rutin, o-coumaric acid, and ellagic acid components detected in the $\mathrm{Cd}$ methanolic extract exhibited strong antioxidant and antimicrobial activities [12,31,32,35-38]. According to the results obtained for the small intestinal and cecal microflora composition, we suggest that the phenolic compounds of $\mathrm{Cd}$ can inhibit the growth of pathogenic bacteria (Salmonella and Coliform species) while stimulating the growth of beneficial microbes (yeast and Lactobacillus species) among the intestinal and cecal microbiota in rabbits, thus optimizing the intestinal microbiota ecosystem. Such enhancements in the intestinal microbiota ecosystem can improve the immune status and digestive health of rabbits.

It is worth noting that the inclusion of a powder of $\mathrm{Cd}$ shoots in the diet of rabbits yielded several immunomodulatory effects. These effects occurred mainly through the improvement of the innate immune system, the increase in lysozyme activity, the decrease in the production of the proinflammatory cytokine IL- $\beta 1$, the improvement of the humoral immune system, and the increase in IgG levels. The immunomodulatory effects of the phenolic compounds of the Cd extract, such as rutin, quercetin, kaempferol, and phenolic acids, have been reported in several studies and depend on many factors, such as the bioavailability and chemical structure of the component [39]. Interestingly, many of the phenolic compounds detected in the $\mathrm{Cd}$ methanolic extract are known for their bioavailability because of their increased intestinal absorbance ability. For example, Manach et al. [40] suggested that GA and isoflavones, catechins, flavanones, and quercetin glucosides are among the most well-absorbed phenolic compounds, whereas the least well-absorbed compounds are proanthocyanidins and anthocyanins. In this context, ellagic acid, which was detected in abundance in the $\mathrm{Cd}$ methanolic extract, has been found to significantly increase the serum IgM and IgG levels, whereas both $\operatorname{Ig} A$ and IgE remain unchanged [41]. This phenolic acid also exerted an inhibitory effect on IL-1b secretion in ex vivo and in vivo 
experiments [41]. In another study, the IgG response was increased after a treatment with a pomegranate extract rich in polyphenols (16.9\% GA equivalent/day in calves) [42]. As observed here, Cd-treated rabbits had lower rectal temperatures and gastrointestinal microflora homeostasis, which could be attributed to the enhancement of the immune system function. The levels of the inflammatory factors can be increased as a result of a pathogenic infection and are often associated with elevated body temperatures (rectal temperatures) [43]. In our study, the inclusion of $\mathrm{Cd}$ shoots powder in the diets of rabbits decreased the numbers of intestinal and cecal pathogenic bacteria (Salmonella and Coliform). This finding might have explained the decrease in rectal temperature in Cd-treated rabbits. Moreover, the improved lysozyme activity may contribute to the elimination of pathogens because of its enzymatic degradative potential [17]. Finally, increased IgG levels can improve the health of animals in the long term, as these antibodies are responsible for long-term immunological memory [39].

\section{Conclusions}

The results of the present study indicate the impressive range of active phenolic compounds of the shoots of $\mathrm{Cd}$ shrub with a multifunctional biological activity. The $\mathrm{Cd}$ shrub exhibited strong antioxidant and antimicrobial activities, which were confirmed in vitro and in vivo in our study. These results suggest the possibility of using $\mathrm{Cd}$ as an antimicrobial and antioxidant agent. Moreover, this shrub has positive immunomodulatory effects. According to our results, the positive effects of $\mathrm{Cd}$ shoots powder on the health status of rabbits can be obtained in vivo at a level of $1.25-\mathrm{mg} \mathrm{Cd} / \mathrm{kg}$ DM diet. Prospective studies are needed to discover the bioactive natural components of the $\mathrm{Cd}$ extract and their specific biological activities.

Author Contributions: Conceptualization, N.M.H.; methodology, N.M.H. and M.G.S.; investigation, N.M.H. and M.G.S.; resources, N.M.H. and M.G.S.; data curation, N.M.H. and M.G.S.; writingoriginal draft preparation, N.M.H. and M.G.S.; writing—review and editing, N.M.H.; and visualization, N.M.H. and M.G.S. All authors have read and agreed to the published version of the manuscript.

Funding: This research received no external funding.

Institutional Review Board Statement: The study was conducted according to the guidelines of the Declaration of Pharmaceutical \& Fermentation Industries Development Center and approved by the Institutional Animal Care and Use Committee (IAUCU) of SRTA-city (protocol code \#31-1Z-0521).

Data Availability Statement: Data of this study are confidential.

Conflicts of Interest: The authors declare no conflict of interest.

\section{References}

1. Hashem, N.; Soltan, Y.; El-Desoky, N.; Morsy, A.; Sallam, S. Effects of Moringaoleifera extracts and monensin on performance of growing rabbits. Livest. Sci. 2019, 228, 136-143. [CrossRef]

2. Awad, O.M.E.; El Sohaimy, S.; Ghareeb, D.A.; Aboulenein, A.; Saleh, S.R.; El-Aziz, N.M.A. Phytochemical analysis and toxicity assessment of artichoke by-product extract. Pak. J. Biol. Sci. 2019, 23, 81-91. [CrossRef] [PubMed]

3. Moustafa, A.; Sarah, R.; Qiqa, S.; Mansour, S.; Alotaibi, M. Cleome droserifolia: An Egyptian natural heritage facing extinction. Asian J. Plant Sci. Res. 2019, 9, 14-21.

4. El-Askary, H.; Handoussa, H.; Badria, F.; El-Khatib, A.H.; Alsayari, A.; Linscheid, M.W.; Motaal, A.A. Characterization of hepatoprotective metabolites from Artemisia annua and Cleome droserifolia using HPLC/PDA/ESI/MS-MS. Rev. Bras.Farm. 2019, 29, 213-220. [CrossRef]

5. Abdel-Kader, M.S.; Alqasoumi, S.I.; Al-Taweel, A.M. Hepatoprotective constituents from Cleome droserifolia. Chem. Pharm. Bull. 2009, 57, 620-624. [CrossRef]

6. Ezzat, S.M.; Motaal, A.A. Isolation of new cytotoxic metabolites from Cleome droserifolia growing in Egypt. Z. FürNat. C 2012, 67, 266-274. [CrossRef]

7. Maksoud, H.A.; Zaid, O.A.A.; Elharrif, M.G.; Omnia, M.; Alaa, E. Selenium Cleome droserifolia nanoparticles (Se-CNPs) and it's ameliorative effects in experimentally induced diabetes mellitus. Clin. Nutr. ESPEN 2020, 40, 383-391. [CrossRef] [PubMed]

8. Motaal, A.; Ezzat, S.; El-askary, H. Antihyperglycemic Activity and standardization of the bioactive extract of Ceome droserifolia growing in Egypt. Pharmacogn. J. 2014, 6, 15-21. [CrossRef] 
9. Shehata, M.G.; Ahmad, F.T.; Badr, A.N.; Masry, S.H.; El-Sohaimy, S.A. Chemical analysis, antioxidant, cytotoxic and antimicrobial properties of propolis from different geographic regions. Ann. Agric. Sci. 2020, 65, 209-217. [CrossRef]

10. Ma, X.; Laaksonen, O.; Zheng, J.; Yang, W.; Trépanier, M.; Kallio, H.; Yang, B. Flavonol glycosides in berries of two major subspecies of sea buckthorn (Hippophaë rhamnoides L.) and influence of growth sites. Food Chem. 2016, 200, 189-198. [CrossRef] [PubMed]

11. Teleszko, M.; Wojdyło, A.; Rudzińska, M.; Oszmiański, J.; Golis, T. Analysis of lipophilic and hydrophilic bioactive compounds content in sea buckthorn (Hippophä̈ rhamnoides L.) Berries. J. Agric. Food Chem. 2015, 63, 4120-4129. [CrossRef]

12. Shehata, M.G.; Abu-Serie, M.M.; El-Aziz, N.M.A.; El-Sohaimy, S.A. Nutritional, phytochemical, and in vitro anticancer potential of sugar apple (Annona squamosa) fruits. Sci. Rep. 2021, 11, 1-13. [CrossRef]

13. Panda, S.K.; Mohanta, Y.K.; Padhi, L.; Park, Y.-H.; Mohanta, T.K.; Bae, H. Large scale screening of ethnomedicinal plants for identification of potential antibacterial compounds. Molecules 2016, 21, 293. [CrossRef]

14. National Research Council (NRC). Nutrient Requirements of Rabbits, 2nd ed.; National Academy Press: Washington, DC, USA, 1977; p. 24.

15. Phuoc, T.L.; Jamikorn, U. Effects of probiotic supplement (Bacillus subtilis and Lactobacillus acidophilus) on feed efficiency, growth performance, and microbial population of weaning rabbits. Asian-Australas. J. Anim. Sci. 2016, 30, 198-205. [CrossRef] [PubMed]

16. Calder, P.C. Immunological parameters: What do they mean? J. Nutr. 2007, 137, 773S-780S. [CrossRef] [PubMed]

17. Ishii, S.; Matsuura, A.; Itakura, E. Identification of a factor controlling lysosomal homeostasis using a novel lysosomal trafficking probe. Sci. Rep. 2019, 9, 1-12. [CrossRef]

18. Pourakbari, M.; Seidavi, A.; Asadpour, L.; Martínez, A. Probiotic level effects on growth performance, carcass traits, blood parameters, cecal microbiota, and immune response of broilers. An. Acad. Bras. Ciênc. 2016, 88, 1011-1021. [CrossRef]

19. Lovie, P. Book Review: Everitt, B.S.; Dunn, G. Applied Multivariate Data Analysis. London: Edward Arnold. $316 p p . £ 29.95$ PB. ISBN 034054529 1. Stat. Methods Med. Res. 1993, 2, 114-115. [CrossRef]

20. Badr, A.N.; Abdel-Razek, A.G.; Youssef, M.M.; Shehata, M.G.; Hassanein, M.M.; Amra, H.A. Natural antioxidants: Preservation roles and mycotoxicological safety of food. Egypt. J. Chem. 2020, 64, 285-298. [CrossRef]

21. Yasmin, F.; Yusoff, N.A.; Hossain, A. Phytochemical screening and pharmacological activities of the ethanolic stem extract of Cleome gynandra. Pak. J. Nutr. 2020, 19, 153-159. [CrossRef]

22. Aicha, M.; Nadia, Z.; Sihem, H.; Abdelmalik, B. Antioxidant activity and phenolic compounds contents of spider flower (Cleome Arabica ssp. Arabica), a well acclimated species in the Algerian desert areas. Eur. Sci. J. ESJ 2017, 13, 13. [CrossRef]

23. Hashem, N.M.; Gonzalez-Bulnes, A.; Simal-Gandara, J. Polyphenols in farm animals: Source of reproductive gain or waste? Antioxidants 2020, 9, 1023. [CrossRef]

24. Badr, A.N.; Gromadzka, K.; Shehata, M.G.; Stuper-Szablewska, K.; Drzewiecka, K.; Abdel-Razek, A.G.; Youssef, M.M. Encapsulated bioactive ingredients of grape by-products applicate in fresh-cut fruit and juices diminished the ochratoxins. J. Food Process. Preserv. 2021, 45. [CrossRef]

25. El-Gawad, A.M.A.; El-Amier, Y.A.; Bonanomi, G. Essential oil composition, antioxidant and allelopathic activities of Cleome droserifolia (Forssk.) Delile. Chem. Biodivers. 2018, 15, e1800392. [CrossRef] [PubMed]

26. Badr, A.; Ali, H.; Abdel-Razek, A.; Shehata, M.; Albaridi, N. Bioactive components of pomegranate oil and their influence on mycotoxin secretion. Toxins 2020, 12, 748. [CrossRef]

27. Ismael, N.M.M.; Shehata, M.G. Improvement of lipid profile and antioxidant of hyperlipidemic albino rats by functional Plantago psyllium Cake. Curr. Res. Nutr. Food Sci. J. 2020, 8, 424-437. [CrossRef]

28. Harzallah, A.; Bhouri, A.M.; Amri, Z.; Soltana, H.; Hammami, M. Phytochemical content and antioxidant activity of different fruit parts juices of three figs (Ficuscarica L.) varieties grown in Tunisia. Ind. Crop. Prod. 2016, 83, 255-267. [CrossRef]

29. Shehata, M.G.; Darwish, A.; El Sohaimy, S. Physicochemical, structural and functional properties of water-soluble polysaccharides extracted from Egyptian agricultural by-products. Ann. Agric. Sci. 2020, 65, 21-27. [CrossRef]

30. Hashem, N.; Hassanein, E.; Simal-Gandara, J. Improving reproductive performance and health of mammals using honeybee products. Antioxidants 2021, 10, 336. [CrossRef]

31. Muhaidat, R.; Al-Qudah, M.A.; Samir, O.; Jacob, J.H.; Hussein, E.; Al-Tarawneh, I.N.; Bsoul, E.; Orabi, S.T.A. Phytochemical investigation and in vitro antibacterial activity of essential oils from Cleome droserifolia (Forssk.) Delile and C. trinervia Fresen. (Cleomaceae). S. Afr. J. Bot. 2015, 99, 21-28. [CrossRef]

32. Al-Mugdadi, S.F.H.; Al-Sudani, B.; Mohsin, R.A.; Mjali, A.J. Anticarcinogenic and antimicrobial activity effects of the ellagic acid extract. Int. J. Res. Pharm. Sci. 2019, 10, 1172-1180. [CrossRef]

33. Velika, B.; Kron, I. Antioxidant properties of benzoic acid derivatives against superoxide radical. Free Radic. Antioxid. 2012, 2, 62-67. [CrossRef]

34. Koul, B.; Chase, N. Moringa oleifera Lam: Panacea to several maladies. J. Chem. Pharm. Res. 2015, 7, 687-707.

35. Park, E.-S.; Moon, W.-S.; Song, M.-J.; Kim, M.-N.; Chung, K.-H.; Yoon, J.-S. Antimicrobial activity of phenol and benzoic acid derivatives. Int. Biodeterior. Biodegrad. 2001, 47, 209-214. [CrossRef]

36. Arima, H.; Ashida, H.; Danno, G.-I. Rutin-Enhanced antibacterial activities of flavonoids against Bacillus cereus and Salmonella enteritidis. Biosci. Biotechnol. Biochem. 2002, 66, 1009-1014. [CrossRef] 
37. Céliz, G.; Daz, M.; Audisio, M. Antibacterial activity of naringin derivatives against pathogenic strains. J. Appl. Microbiol. 2011, 111, 731-738. [CrossRef]

38. Bassolé, I.H.N.; Juliani, H.R. Essential oils in combination and their antimicrobial properties. Molecules 2012, $17,3989-4006$. [CrossRef] [PubMed]

39. Chen, L.; Wei, Y.; Zhao, S.; Zhang, M.; Yan, X.; Gao, X.; Li, J.; Gao, Y.; Zhang, A.; Gao, Y. Antitumor and immunomodulatory activities of total flavonoids extract from persimmon leaves in H22 liver tumor-bearing mice. Sci. Rep. 2018, 8, 10523. [CrossRef]

40. Manach, C.; Williamson, G.; Morand, C.; Scalbert, A.; Rémésy, C. Bioavailability and bioefficacy of polyphenols in humans. I. Review of 97 bioavailability studies. Am. J. Clin. Nutr. 2005, 81, 230S-242S. [CrossRef] [PubMed]

41. Allam, G.; Abuelsaad, A.; Alblihed, M.A.; Alsulaimani, A.A. Ellagic acid reduces murine schistosomiasis mansoni immunopathology via up-regulation of IL-10 and down-modulation of pro-inflammatory cytokines production. Immunopharmacol. Immunotoxicol. 2016, 38, 286-297. [CrossRef]

42. Oliveira, R.; Narciso, C.; Bisinotto, R.; Perdomo, M.; Ballou, M.; Dreher, M.; Santos, J. Effects of feeding polyphenols from pomegranate extract on health, growth, nutrient digestion, and immunocompetence of calves. J. Dairy Sci. 2010, 93, 4280-4291. [CrossRef] [PubMed]

43. Tesch, T.; Bannert, E.; Kluess, J.; Frahm, J.; Hüther, L.; Kersten, S.; Breves, G.; Renner, L.; Kahlert, S.; Rothkötter, H.-J.; et al. Relationships between body temperatures and inflammation indicators under physiological and pathophysiological conditions in pigs exposed to systemic lipopolysaccharide and dietary deoxynivalenol. J. Anim. Physiol. Anim. Nutr. 2017, 102, 241-251. [CrossRef] 